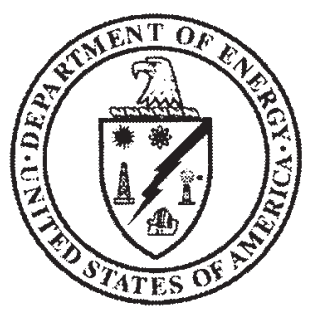

U.S. Department of Energy Idaho Operations Office

\title{
Idaho National Laboratory (INL) Site Greenhouse Gas (GHG) Monitoring Plan - 40 CFR 98
}

July 2010 
DOE/ID-11432

\section{Idaho National Laboratory (INL) Site Greenhouse Gas (GHG) Monitoring Plan - 40 CFR 98}

July 2010 


\section{CONTENTS}

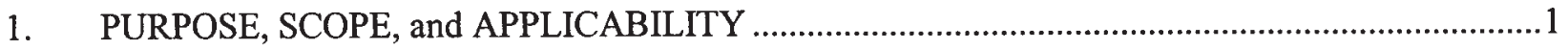

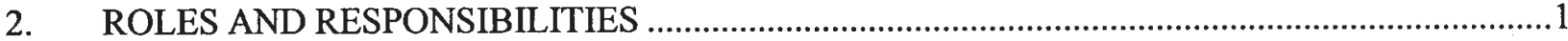

3. PROCESSES AND METHODOLOGIES USED TO COLLECT DATA FOR GHG

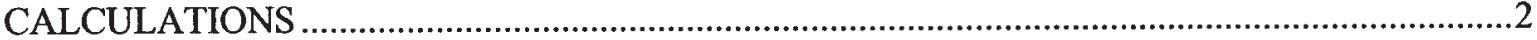

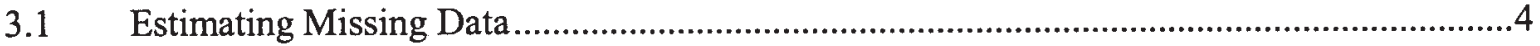

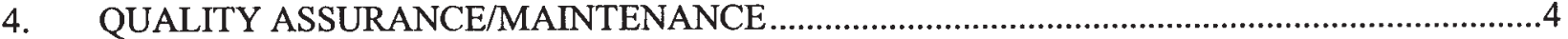

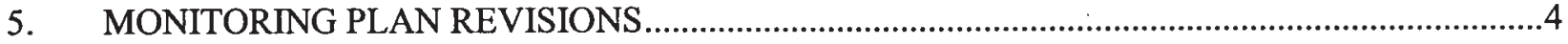

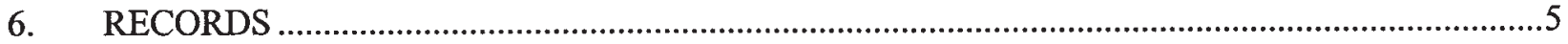

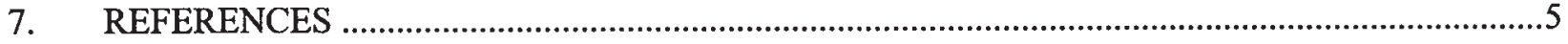

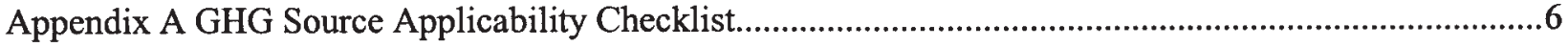

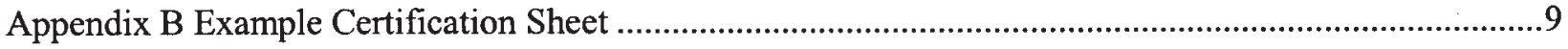

\section{TABLES}

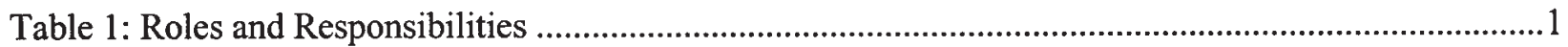

Table 2: GHG Data Collection for Annual INL Site GHG Emission Reporting .........................................3 


\section{PURPOSE, SCOPE, and APPLICABILITY}

The purpose of this Greenhouse Gas (GHG) Monitoring Plan is to meet the monitoring plan requirements of Title 40 of the Code of Federal Regulations Part 98.3(g)(5). This GHG Monitoring Plan identifies procedures and methodologies used at the Idaho National Laboratory Site (INL Site) to collect data used for GHG emissions calculations and reporting requirements from stationary combustion and other regulated sources in accordance with 40 CFR 98, Subparts A and other applicable subparts. INL Site Contractors determined subpart applicability through the use of a checklist (Appendix A). Each facility/contractor reviews operations to determine which subparts are applicable and the results are compiled to determine which subparts are applicable to the INL Site. This plan is applicable to the 40 CFR 98-regulated activities managed by the INL Site contractors: Idaho National Laboratory (INL), Idaho Cleanup Project (ICP), Advanced Mixed Waste Treatment Project (AMWTP), and Naval Reactors Facilities (NRF).

\section{ROLES AND RESPONSIBILITIES}

Data collection in accordance with this GHG Monitoring Plan will be completed by assigned coordinators (Table 1) from each of the INL Site contractors and consolidated into the annual Site GHG Emissions Report by designated INL resources. INL will submit a Sitewide report to the Department of Energy - Idaho (DOE-ID) for submittal to the U.S. Environmental Protection Agency (EPA) - Region 10 by March $31^{\text {st }}$ of each year for the previous calendar year. Each point of contact will obtain certification from the appropriate certifying official.

Table 1: Roles and Responsibilities

\begin{tabular}{|l|l|}
\hline \multicolumn{1}{|c|}{$\begin{array}{c}\text { DOE-ID and INL Site Contractor Points of } \\
\text { Contact (Positions) }\end{array}$} & \multicolumn{1}{|c|}{ Responsibility } \\
\hline $\begin{array}{l}\text { DOE-ID: Designated representative for INL } \\
\text { Site }\end{array}$ & $\begin{array}{l}\text { INL Site Annual GHG Emission Report certification, } \\
\text { signing, and submittal to Region 10 of EPA. } \\
\text { Transmittal to EPA Region 10 no later than March 31 } \\
\text { of each year. }\end{array}$ \\
\hline $\begin{array}{l}\text { INL: INL Air Permitting and Reporting } \\
\text { Lead }\end{array}$ & $\begin{array}{l}\text { Develop a reporting and deliverable schedule and } \\
\text { distribute by December } 1^{\text {st }} \text { of current reporting year. } \\
\text { Review INL operations to determine which subparts } \\
\text { are applicable during annual review of GHG } \\
\text { Monitoring Plan. Data collection and contractor data } \\
\text { certification for the INL Site. } \\
\text { INL Site report preparation, contractor certification } \\
\text { and submittal to DOE-ID. Report submitted to DOE- } \\
\text { ID no later than March } 1^{\text {st }}\end{array}$ \\
\hline $\begin{array}{l}\text { AMWTP: Environmental Engineering Lead, } \\
\text { Air }\end{array}$ & $\begin{array}{l}\text { Review AMWTP operations to determine which } \\
\text { subparts are applicable during annual review of GHG } \\
\text { Monitoring Plan. Data collection, contractor data } \\
\text { certification, and transmittal of AMWTP information } \\
\text { to INL contractor per annual schedule. }\end{array}$ \\
\hline
\end{tabular}




\begin{tabular}{|l|l|}
\hline $\begin{array}{c}\text { DOE-ID and INL Site Contractor Points of } \\
\text { Contact (Positions) }\end{array}$ & \multicolumn{1}{|c|}{ Responsibility } \\
\hline $\begin{array}{l}\text { ICP: ICP Air Quality Technical } \\
\text { Representative }\end{array}$ & $\begin{array}{l}\text { Review ICP operations to determine which subparts } \\
\text { are applicable during annual review of GHG } \\
\text { Monitoring Plan. Data collection, contractor data } \\
\text { certification, and transmittal of ICP information to } \\
\text { INL contractor per annual schedule. }\end{array}$ \\
\hline NRF: Environmental Engineering, Air & $\begin{array}{l}\text { Review NRF operations to determine which subparts } \\
\text { are applicable during annual review of GHG } \\
\text { Monitoring Plan. Data collection, contractor data } \\
\text { certification, and transmittal of NRF information to } \\
\text { INL contractor per annual schedule. }\end{array}$ \\
\hline
\end{tabular}

Each facility/contractor at the INL Site is responsible for collecting fuel use and emission information as required in 40 CFR 98.3, submitting certified data for each of their sources to the INL Environmental Support and Services for rollup into a single report submission for the INL Site, and maintaining appropriate data support records as described in 40 CFR 98.36-37.

The reporting period for the Annual INL Site GHG Emissions Report is from January 1 through December 31 of each calendar year. The deliverable will consist of a consolidated INL compliance certification of individual facility/contractor compliance of GHG emission monitoring data and supporting documentation. Each facility/contractor will monitor and report their applicable fuel use and emissions data from their applicable stationary combustion sources, including accounting for missing data information and calculating estimates. Monitoring data will be certified and submitted to INL contractor Environmental Support and Services Directorate by February $15^{\text {th }}$, for roll up of the INL Site monitoring data. DOE-ID will certify the consolidated report as required by regulation and transmit to EPA Region 10.

\section{PROCESSES AND METHODOLOGIES USED TO COLLECT DATA FOR GHG CALCULATIONS}

The INL Site will be using Tier I calculation methodologies for reporting GHG emissions from stationary fuel combustion sources. The data to be collected for the Tier I calculations for stationary sources subject to 40 CFR 98 consist primarily of the following information records (Table 2). These records are created, collected, and managed according to INL Site contractor-specific controlled procedures. These contractor-specific documents and procedures include operation specific procedures and maintenance procedures/preventative maintenance work orders and applicable environmental and chemical management procedures. The contractor-controlled documents include applicable quality assurance and record keeping requirements and implementation instructions for compliance with 40 CFR 98. Contractors will supply supporting documentation that includes a list of reference documents/procedures used to collect data for generation of the Annual INL Site GHG Emissions Report. 
Table 2: GHG Data Collection for Annual INL Site GHG Emission Reporting

\begin{tabular}{ll}
\hline Stationary Source Unit Type & Fuel Use Information \\
\hline Boilers (Diesel, Propane) & $\begin{array}{l}\text { Individual unit meters (fuel usage meters), } \\
\text { Fuel delivery receipts }\end{array}$ \\
$\begin{array}{l}\text { Generators, Compressors, Pumps (non-emergency, } \\
\text { non-portable, diesel, propane, or gasoline) }\end{array}$ & Individual fuel usage or run time unit meters, \\
$\begin{array}{l}\text { Small heater/building units (propane): (i.e.: space } \\
\text { heating, hot water heaters) }\end{array}$ & Fuel delivery receipts \\
Incinerator (solid biomass fuel) & Individual unit meters (fuel usage meters) \\
\hline
\end{tabular}

According to 40 CFR 98.36(c)(1), data collected from each stationary source or aggregated source for the annual INL Site GHG Emission Report shall include:

- Unit/Group identification number(s);

- Code representing type of unit;

- Maximum heat input rating in million British Thermal Units per hour (MMBTU/hr) (for boilers and process heaters only);

- Cumulative maximum rated heat input capacity of the group (if aggregating units);

- Relative units of measure for other combustion sources (i.e.: HP rating, BTU rating);

- Customer meter number (for any units that combust natural gas);

- Type of fuel combusted; and

- Annual calendar year amount of fuel combusted (in gallons for liquids, short tons for solids, and standard cubic feet for gaseous).

According to 40 CFR 98.36 (c)(1), the INL Site may use aggregation of units as an alternative to reporting GHG emissions from individual units. In order to aggregate emissions, the INL Site must contain two or more units, each of which has a maximum rated heat input capacity of $250 \mathrm{MMBTU} / \mathrm{hr}$ or less. Data can be collected by a group of units, rather than by each individual unit.

Each year facility/contractor data packages will be submitted to INL Environmental Support and Services Directorate by the second Thursday in February. An electronic file containing the reporting data and attachments should be provided to the INL Air Permitting and Reporting Lead with INL Environmental Support and Services for compiling the data into the Annual INL Site GHG Emissions Report.

\section{Certification Statement}

GHG emission report submittals will be certified in accordance with respective contract requirements to the INL Environmental Support and Services Directorate. Each facility/contractor will certify that the data is true, accurate and complete to the best of their knowledge (see Appendix B example). 


\subsection{Estimating Missing Data}

In the event of missing data, the following approaches will be used to estimate missing data values.

\section{Individual Unit Meters}

If individual unit meters malfunction or are not within calibration, fuel usage calculations will be made from the best available information, such as:

1. Available fuel receipt information (for units with dedicated supply/storage tanks)

2. Recorded equipment operation hour run times, size of each combustion unit, and manufacturer information on hourly consumption rate at identified loading. Manufacturer information will be consulted to determine fuel consumption from horsepower (hp) ratings, if applicable. If no manufacturer information is available, average fuel usage data will be used.

\section{Fuel Delivery Receipts}

If fuel delivery receipts are unavailable or missing for a particular delivery, estimates of fuel usage will be made from the best available information, such as:

1. Average of fuel receipt deliveries for the specific unit for the reporting period, in the case of missing receipts from a particular delivery, or

2. Recorded equipment operation hour run times and manufacturer information on hourly consumption rate at identified loading.

\section{QUALITY ASSURANCE/MAINTENANCE}

There are no monitoring and quality assurance/quality control requirements identified in 40 CFR 98.34 for Tier I calculations; therefore, ensuring facility/contractor data quality and maintaining and calibrating measurement devices in accordance with manufacturer's recommendations satisfy the quality assurance criteria for this INL Site GHG Monitoring Plan. As previously identified, supporting documentation will be provided that identifies procedures used to collect data for the annual INL Site GHG Monitoring Report. In accordance with 40 CFR 98.3(h)(i)(1), the facility/contractor will ensure the quality of the data used for GHG emissions calculations by properly calibrating and maintaining fuel meter measurement devices in accordance with manufacturer's recommendations and the fuel meter measurement devices must be calibrated to an accuracy of five percent. Information provided in INL Site contractor data submittals will be contractor certified as being true, accurate and complete, having been prepared in accordance with all applicable requirements.

\section{MONITORING PLAN REVISIONS}

As described in 40 CFR 98.3(g)(5)(iii), revisions to this INL Site GHG Monitoring Plan will be made as necessary to reflect changes in production processes, monitoring instrumentation, and quality assurance procedures; or to improve procedures for the maintenance and repair of monitoring systems to reduce the frequency of monitoring equipment downtime. Per DOE-ID requirements, the INL Site GHG Monitoring Plan will be reviewed annually (last quarter of calendar year). 


\section{RECORDS}

In accordance with 40 CFR 98.3(g)(5)(iv), "[u]pon request by the [EPA], the owner or operator shall make all information that is collected in conformance with the INL Site GHG Monitoring Plan available for review during an audit. Electronic storage of the information in the plan is permissible, provided that the information can be made available in hard copy upon request during an audit."

According to 40 CFR $98.3(\mathrm{~g})$, records required to be maintained for a minimum of three years include:

- Procedures used to ensure the accuracy of the estimates of fuel usage and boiler efficiency (as applicable, per 40 CFR 98.34(g))

- Unit Fuel usage meter data, as applicable

- Unit Fuel delivery receipts, as applicable

- Unit Combustion source operational run times, as applicable

- Missing Data Calculations, as applicable

- Unit Fuel meter calibration and maintenance records, as applicable

- Annual Site contractor data submittals, with contractor certifications

- Annual Site GHG Emissions Report and transmittals, with certifications

\section{REFERENCES}

40 CFR 98, Subparts A and C, “General Stationary Fuel Combustion Sources.” Environmental Protection Agency, Code of Federal Regulations, current issue. 


\section{Appendix A}

\section{GHG Source Applicability Checklist}

\begin{tabular}{|c|c|c|c|c|c|}
\hline \multicolumn{6}{|c|}{ Greenhouse Gas Monitoring Plan - Source Applicability Determination Checklist } \\
\hline Contractor: & \multicolumn{2}{|c|}{ Facility/Bddgs: } & & & \\
\hline \multicolumn{4}{|c|}{$\begin{array}{l}\text { Do any of your facilities operate non-electric stationary combustion sources? (40 CFR } 98 \text { Subpart C) } \\
\text { (pontable and emergency equipment are exempt from reporting requirements) }\end{array}$} & $\square$ Yes & $\square$ No \\
\hline \multicolumn{2}{|c|}{\begin{tabular}{l|l|} 
If yes, mark fuel types used: \\
\end{tabular}} & $\square$ Gasoline & $\square$ Propane & $\square$ Natural Gas & $\square$ Biomass \\
\hline \multicolumn{6}{|c|}{ If other, please list: } \\
\hline \multicolumn{2}{|c|}{ If yes, mark equipment types used: $\square$ Generator } & $\square$ Boiler & $\square$ Water/Space Heater & $\square$ Furnace & $\square$ Incinerator \\
\hline
\end{tabular}

\begin{tabular}{|c|c|c|}
\hline $\begin{array}{l}\text { Do any of your facilities operate electricity genera tion units subject to the requirements of the } \\
\text { Acid Rain Program or required to monitor and report } \mathrm{CO}_{2} \text { emissions year round? ( } 40 \mathrm{CFR} 98 \text { subpart D) } \\
\text { (portable and emergency equipment are exempt from reporting requirements) }\end{array}$ & $\square$ Yes & $\square$ No \\
\hline Do any of your facilities produce adipic acid using oxidation? (40 CFR $\$ 8$ Subpart E) & $\square$ Yes & No \\
\hline $\begin{array}{l}\text { Do any of your facilities manufacture primary aluminum? ( } 40 \text { CFR } 98 \text { subpart } \mathrm{A} \text { ) } \\
\text { (does not include experimental cells or research and development process units) }\end{array}$ & $\square$ Yes & $\square$ No \\
\hline Do any of your facilities operate ammonia manufacturing process units? ( 40 CFR 98 Subparr $G$ ) & Yes & Do \\
\hline Do any of your facilities manufacture portland cement? (40 CFR 98 Subpart $H$ ) & $\square$ Yes & No \\
\hline $\begin{array}{l}\text { Do any of your facilities produce ferroalloys (ferrochromium, ferromanganese, ferromolybdenum, } \\
\text { ferronickel, ferrosilicon, ferrotitanium, ferrotungsten, ferrovanadium, silicomanganese, or silicon metal)? } \\
\text { ( } 40 \text { CFR } 98 \text { Subpart } K \text { ) }\end{array}$ & TYes & $\square$ No \\
\hline $\begin{array}{l}\text { Do any of your facilities manufacture flat glass, container glass, pressed or blown glass, or wool } \\
\text { fiberglass? ( } \$ 0 \text { CFR } 98 \text { Subport } N \text { ) (does not include experimental furnaces or research and development process units) }\end{array}$ & DYes & $\square$ No \\
\hline Do any of your facilities produce HCFC-22 and/or destruct HFC-23? (40 CFR 98 Subpart O) & Wes & Do \\
\hline Do any of your facilities produce hydrogen gas sold as a product to other entities? ( 40 CFR 98 Subpart P) & Yes & $\square$ No \\
\hline Do any of your facilities produce iron and steel? (40 CFR 98 Subpart $Q$ ) & $\square$ Yes & $\square$ No \\
\hline Do any of your facilitles operate as primary or secondary lead smelters? ( 40 CFR 98 subpart 8 ) & $\square$ Yes & $\square$ No \\
\hline $\begin{array}{l}\text { Do any of your facilities manufacture lime products (e.g. calcium oxide, high-calcium quicklime, } \\
\text { calcium hydroxide, hydrated lime, dolomitic quicklime, dolomitic hydrate)? (40 CFR } 98 \text { Subpart S) }\end{array}$ & $\square$ Yes & $\square$ No \\
\hline $\begin{array}{l}\text { Do any of your facilities produce magnesium or use molten magnesium in alloying, casting, drawing } \\
\text { extruding, forming, or rolling operations? (40 CFR } 98 \text { Subpart } T \text { - not reportable until } 2011)\end{array}$ & $\square$ Yes & $\square$ No \\
\hline $\begin{array}{l}\text { Do any of your facilities operate equipment that uses carbonates (limestone, magnesite, dolomite, } \\
\text { siderite, ankerite, rhodochrosite, or sodium carbonate/soda ash)? ( } 40 \text { CFR } 98 \text { Subpart U) }\end{array}$ & Q Yes & $\mathrm{D}$ No \\
\hline Do any of your facilities produce nitric acid? (40 CFA 98 Subpart $h$ & $\square$ Yes & $\square$ No \\
\hline $\begin{array}{l}\text { Do any of your facilities produce petrochemicals (i.e. include processes that produce acrylonitrile, } \\
\text { carbon black, ethylene, ethylene dichloride, ethylene oxide, or methanol)? ( } 40 \text { CFR } 98 \text { subpart X) }\end{array}$ & $\square$ Yes & $\square$ No \\
\hline Do any of your facilities operate as a petroleum refinery? (40 CFR 98 subpart $n$ ) & $\square$ Yes & $\square$ No \\
\hline Do any of your facilities operate a wet-process phosphoric acid production line? ( 40 CFR 98 subpart $Z$ ) & $\square$ Yes & $\square$ No \\
\hline Do any of your facilities manufacture pulp and paper? (40 CFR 98 Subpart $A A$ ) & $\square$ Yes & No \\
\hline Do any of your facilities produce silicon carbide for abra sive purposes? ( 40 CFR 98 Subpart BE) & $\square$ Yes & $\square$ No \\
\hline Do any of your facilities manufacture soda ash? ( 40 CFR 98.5 ubparr CO & $\square$ Yes & $\square$ No \\
\hline Do any of your facilities produce titanium dioxide? (40 CFR 98 Subpart EE) & D Yes & $\square$ No \\
\hline
\end{tabular}




Contractor: $\quad$ Facility/Bldgs:

Do any of your facilities opera te underground coal mines or under development with an operational pre-mining degasification system? (40 CFR 98 Subpart FF - not reportable until 2011) Y Yes Do any of your facilities operate zinc smelters or secondary zinc recycling facilities? (40 CFR 98 Subpart GG)

Do any of your facilities operate municipal solid waste landfills (includes landfill gas collection systems and landfill gas destruction devices)? ( $\$ 0$ CFR 98 Subpart $\mathrm{HH}$ )

(does not include hazardous waste, construction and demolition, or industrial landfills)

$\square$ Yes

No

\begin{tabular}{lll}
$\square$ Yes $\square$ No \\
\hline
\end{tabular}

Do any of your facilities operate industrial wastewater trea tment systems (only applicable at the following operations - pulp and paper manufacturing, food processing, ethanol production, or petroleum refining)? (40 CFR 98 subpart II - not reportable until 2011)

TYes

DYes

Do any of your facilities produce, import, or export coal-based liquid fuels? (40 CFR 98 Subparr LL)

Yes

Do any of your facilities produce, import, export, or supply petroleum products?

(40 CFR 98 Subpart MM)

Do any of your facilities operate as natural gas liquids fractionators or local natural gas distribution Companies? (40 CFR 98 SUbpart NM)

Do any of your facilities produce a fluorinated greenhouse gas or nitrous oxide, import fluorinated greenhouse gases or nitrous oxide in bulk, or export fluorinated greenhou se gases or nitrous oxide in bulk ? (40 CFR 98 Subpart OO)

$\square$ Yes $\square$ No

Do any of your facilities contain production process units or production wells that capture a $\mathrm{CO}_{2}$ stream for purposes of supplying $\mathrm{CO}_{2}$ for commercial applications or capture and maintain custody of a $\mathrm{CO}_{2}$ stream in order to sequester or otherwise inject it underground? Bulk importer or exporter of $\mathrm{CO}_{2}$ ? (40 CFR 98 Subpart PP)

(storage of $\mathrm{CO}_{2}$ above ground or in geologic formations; use of $\mathrm{CO}_{2}$ in enhanced oil an gas recovery; transportation or

distribution of $\mathrm{CO}_{2}$; purification, compression, or processing of $\mathrm{CO}_{2}$; on-site use of $\mathrm{CO}_{2}$ captured on site; and $\mathrm{CO}_{2}$ imported or exported in equipment are excluded from reporting requirements)

Do any of your facilities operate industrial landfill 5 with a total landfill design capacity greater than or equal to 300,000 metric tons? (40 CFR 98 Subpart TT-not reportable until 2011 )

(dedicated construction and demolition waste land fills, industrial landfills that only receive inert wastes (fly ash, cement kiln

dust rocks and/or soll from excavation and construction activities, glass, non-chemically bound sand, clay, gypsum, pottery cull

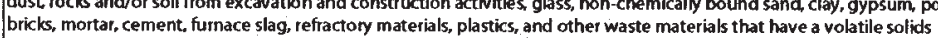

concentration of 05 weight percent (on a dry basis) or less) are excluded from reporting requirements)

$\square$ Yes $\square$ No

Comments: 
I certify that, based on reasonable inquiry, the information provided in this submittal has been prepared in accordance with all applicable requirements and is to the best of my knowledge and belief, true, accurate, and complete.

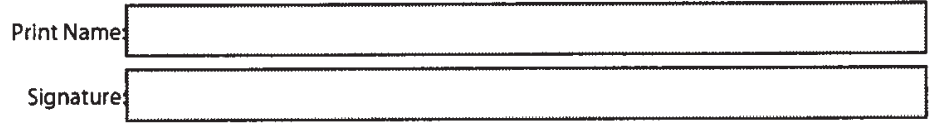

Date

Submit by E-mail

Note: The following subparts are [reserved] and will be incorporated into this checklist once they are finalized in 40 CFR 98:

Subpart B, Subpart I, Subpart J, Subpart L, Subpart M, Subpart W, Subpart DD, Subpart KK, Subpart QQ.

Subpart RR, and Subpart $\$ S$.

Page 3 of 3

\section{Click here to access form for completion}




\title{
Appendix B
}

\section{Example Certification Sheet}

\author{
INSERT Facility Name \\ 2010 Annual GHG Emissions Reporting for the \\ Reporting Period January 01, 2010 through December 31, 2010
}

I certify that, based on reasonable inquiry, the information provided in this submittal has been prepared in accordance with all applicable requirements and is to the best of my knowledge and belief, true, accurate, and complete.

Program / Project Director:

Date: (INSERT Typed Name)

Or

Program / Project Manager:

Date: (INSERT Typed Name) 
Contractor:

Facility/BIdgs:

Do any of your facilities operate non-electric stationary combustion sources? (40 CFR 98 Subpart C)

(portable and emergency equipment are exempt from reporting requirements)
If yes, mark fuel types used:
$\square$ Diesel
$\square$ Gasoline
$\square$ Propane

$\square$ Yes $\quad \square$ No

If other, please list:

If yes, mark equipment types used: $\square$ Generator $\quad \square$ Boiler $\quad \square$ Water/ Space Heater $\square$ Furnace $\square$ Incinerator

If other, please list:-

Do any of your facilities operate electricity generation units subject to the requirements of the

Acid Rain Program or required to monitor and report $\mathrm{CO}_{2}$ emissions year round? (40 CFR 98 Subpart D)

(portable and emergency equipment are exempt from reporting requirements)

$\square$ Yes $\square$ No

Do any of your facilities produce adipic acid using oxidation? (40 CFR 98 Subpart E)

$\square$ Yes $\square$ No

Do any of your facilities manufacture primary aluminum? (40 CFR 98 Subpart $F$ )

(does not include experimental cells or research and development process units)

Do any of your facilities operate ammonia manufacturing process units? (40 CFR 98 Subpart G)

Do any of your facilities manufacture portland cement? (40 CFR 98 Subpart $H$ )

$\square$ Yes $\quad \square$ No

$\square$ Yes $\square$ No

Do any of your facilities produce ferroalloys (ferrochromium, ferromanganese, ferromolybdenum,

ferronickel, ferrosilicon, ferrotitanium, ferrotungsten, ferrovanadium, silicomanganese, or silicon metal)?

(40 CFR 98 Subpart K)

$\square$ Yes $\quad \square$ No

Do any of your facilities manufacture flat glass, container glass, pressed or blown glass, or wool

fiberglass? (40 CFR 98 Subpart $N$ ) (does not include experimental furnaces or research and development process units)

Do any of your facilities produce HCFC-22 and/or destruct HFC-23? (40 CFR 98 Subpart O)

$\square$ Yes $\quad \square$ No

Do any of your facilities produce hydrogen gas sold as a product to other entities? (40 CFR 98 Subpart $P$ )

$\square$ Yes $\square$ No

Do any of your facilities produce iron and steel? (40 CFR 98 Subpart Q)

$\square$ Yes $\square$ No

Do any of your facilities operate as primary or secondary lead smelters? (40 CFR 98 Subpart $R$ )

$\square$ Yes

$\square$ No

Do any of your facilities manufacture lime products (e.g. calcium oxide, high-calcium quicklime,

calcium hydroxide, hydrated lime, dolomitic quicklime, dolomitic hydrate)? (40 CFR 98 Subpart S)

$\square$ Yes $\square$ No

Do any of your facilities produce magnesium or use molten magnesium in alloying, casting, drawing

extruding, forming, or rolling operations? (40 CFR 98 Subpart $T$-not reportable until 2011)

Do any of your facilities operate equipment that uses carbonates (limestone, magnesite, dolomite,

siderite, ankerite, rhodochrosite, or sodium carbonate/soda ash)? (40 (FR 98 Subpart U)

Do any of your facilities produce nitric acid? (40 CFR 98 Subpart $V$ )

$\square$ Yes $\quad \square$ No

Do any of your facilities produce petrochemicals (i.e. include processes that produce acrylonitrile, carbon black, ethylene, ethylene dichloride, ethylene oxide, or methanol)? (40 CFR 98 Subpart X)

Do any of your facilities operate as a petroleum refinery? (40 CFR 98 Subpart $h$ )

$\square$ Yes $\square$ No

Do any of your facilities operate a wet-process phosphoric acid production line? (40 CFR 98 Subpart Z)

Do any of your facilities manufacture pulp and paper? (40 CFR 98 Subpart AA)

Do any of your facilities produce silicon carbide for abrasive purposes? (40 CFR 98 SUbpart BB)

Do any of your facilities manufacture soda ash? (40 CFR 98 Subpart CC)

$\begin{array}{ll}\square \text { Yes } & \square \text { No } \\ \square \text { Yes } & \square \text { No }\end{array}$

Do any of your facilities produce titanium dioxide? (40 CFR 98 Subpart EE)

$\square$ Yes $\square$ No

$\square$ Yes $\square$ No

$\square$ Yes $\square$ No

$\square$ Yes $\square$ No

$\square$ Yes $\square$ No

$\square$ Yes $\square$ No

$\square$ Yes $\square$ No


Do any of your facilities operate underground coal mines or under development with an operational

pre-mining degasification system? (40 CFR 98 Subpart FF-not reportable until 2011)

Do any of your facilities operate zinc smelters or secondary zinc recycling facilities?

(40 CFR 98 Subpart GG)

Do any of your facilities operate municipal solid waste landfills (includes landfill gas collection systems

and landfill gas destruction devices)? (40 CFR 98 Subpart HH)

(does not include hazardous waste, construction and demolition, or industrial landfills)

Yes $\square$ No

Do any of your facilities operate industrial wastewater treatment systems (only applicable at the following operations - pulp and paper manufacturing, food processing, ethanol production, or petroleum refining)? (40 CFR 98 Subpart II-not reportable until 2011)

Do any of your facilities operate manure management systems? (40 CFR 98 Subpart JJ)

Do any of your facilities produce, import, or export coal-based liquid fuels? (40 CFR 98 Subpart $L L$ )

Do any of your facilities produce, import, export, or supply petroleum products? (40 CFR 98 Subpart MM)

Do any of your facilities operate as natural gas liquids fractionators or local natural gas distribution companies? (40 CFR 98 Subpart NN)

$\square$ Yes $\square$ No

$\square$ Yes $\quad \square$ No

Do any of your facilities produce a fluorinated greenhouse gas or nitrous oxide, import fluorinated greenhouse gases or nitrous oxide in bulk, or export fluorinated greenhouse gases or nitrous oxide in bulk? (40 CFR 98 Subpart OO)

$\square$ Yes $\quad \square$ No

Do any of your facilities contain production process units or production wells that capture a $\mathrm{CO}_{2}$ stream for purposes of supplying $\mathrm{CO}_{2}$ for commercial applications or capture and maintain custody of a $\mathrm{CO}_{2}$ stream in order to sequester or otherwise inject it underground? Bulk importer or exporter of $\mathrm{CO}_{2}$ ? (40 CFR 98 Subpart PP)

(storage of $\mathrm{CO}_{2}$ above ground or in geologic formations; use of $\mathrm{CO}_{2}$ in enhanced oil an gas recovery; transportation or distribution of $\mathrm{CO}_{2}$; purification, compression, or processing of $\mathrm{CO}_{2}$; on-site use of $\mathrm{CO}_{2}$ captured on site; and $\mathrm{CO}_{2}$ imported or exported in equipment are excluded from reporting requirements)

$\begin{array}{ll}\square \text { Yes } & \square \text { No } \\ \square \text { Yes } & \square \text { No } \\ \square \text { Yes } & \square \text { No }\end{array}$

Do any of your facilities operate industrial landfills with a total landfill design capacity greater than or equal to 300,000 metric tons? (40 CFR 98 Subpart $\pi$ - not reportable until 2011)

(dedicated construction and demolition waste landfills, industrial landfills that only receive inert wastes (fly ash, cement kiln dust, rocks and/or soil from excavation and construction activities, glass, non-chemically bound sand, clay, gypsum, pottery cull, bricks, mortar, cement, furnace slag, refractory materials, plastics, and other waste materials that have a volatile solids concentration of 0.5 weight percent (on a dry basis) or less) are excluded from reporting requirements)

Comments: 
Contractor:

Facility/Bldgs:

I certify that, based on reasonable inquiry, the information provided in this submittal has been prepared in accordance with all applicable requirements and is to the best of my knowledge and belief, true, accurate, and complete.
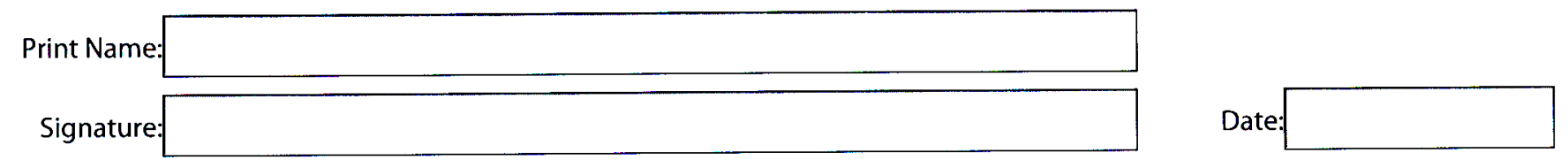

Submit by E-mail

Note: The following subparts are [reserved] and will be incorporated into this checklist once they are finalized in 40 CFR 98 :

Subpart B, Subpart I, Subpart J, Subpart L, Subpart M, Subpart W, Subpart DD, Subpart KK, Subpart QQ,

Subpart RR, and Subpart SS. 